\title{
SIVIM Deciduous Forests - Database of deciduous forests from the Iberian Peninsula
}

\author{
Juan Antonio Campos ${ }^{1}$, Arnau Mercadé 2 , Xavier Font ${ }^{2}$ \\ 1 Department of Plant Biology and Ecology, University of the Basque Country UPV/EHU, Bilbao, Spain \\ 2 Department of Evolutionary Biology, Ecology and Environmental Sciences, University of Barcelona, Barcelona, Spain \\ Corresponding author: Juan Antonio Campos (juanan.campos@ehu.eus)
}

Academic editor: Jürgen Dengler • Received 7 December 2020 • Accepted 10 December 2020 • Published 21 December 2020

\begin{abstract}
"SIVIM Deciduous Forests" is a thematic database established in 2015, focused on forest vegetation from the Iberian Peninsula and southern France. It was registered in the Global Index of Vegetation Databases (GIVD ID: EU-00-023) in January 2016. All types of temperate and submediterranean non-riparian deciduous forests of the phytosociological classes Carpino-Fagetea sylvaticae, Quercetea pubescentis and Quercetea robori-petraeae (formerly combined in the class Querco-Fagetea) are represented in the database. Currently, it contains 6,642 published vegetation plots of beech, birch, ash, lime and other deciduous mixed forests, as well as forests dominated by different species of deciduous and marcescent oaks, $100 \%$ of them classified at association level. Data are stored in TURBOVEG format, and are available upon request from the international vegetation-plot databases EVA and sPlot in semi-restricted regime. The relevés have also been included in SIVIM database, and thus they are freely available online. However, in SIVIM Deciduous Forests geolocation accuracy has been improved and the taxonomy and syntaxonomy unified. Plot size is available for $73 \%$ of the relevés, of which $82 \%$ are between 100 and $400 \mathrm{~m}^{2}$. Plant taxonomy is standardized to Flora iberica. During the last four years, data of SIVIM Deciduous Forests were requested via EVA and sPlot for different projects, and have been used for several studies with various objectives, from floristic, vegetation and habitat-related topics to macroecological studies, and from local to global scales.
\end{abstract}

Abbreviations: EVA = European Vegetation Archive; GIVD = Global Index of Vegetation-Plot Databases; SIVIM = Iberian and Macaronesian Vegetation Information System.

\section{Keywords}

Deciduous forest, Iberian Peninsula, Pyrenees, Querco-Fagetea, relevé, secondary forest, submediterranean forest, temperate forest, vegetation-plot database

Copyright Juan Antonio Campos et al. This is an open access article distributed under the terms of the Creative Commons Attribution License (CC-BY 4.0), which permits unrestricted use, distribution, and reproduction in any medium, provided the original author and source are credited. 


\section{GIVD Fact Sheet}

GIVD Database ID: EU-00-023

Web address:

SIVIM Deciduous Forests

Last update: $2020-12-07$

Database manager(s): Juan Antonio Campos (juanan.campos@ehu.eus)

Owner: Juan Antonio Campos, Arnau Mercadé \& Xavier Font

Scope: Phytosociological relevés of deciduous forest (Carpino-Fagetea sylvaticae, Quercetea pubescentis and Quercetea robori-petraeae classes) in the Iberian Peninsula and southern France.

\section{Abstract:}

Availability: according to a specific agreement

Database format(s): TURBOVEG

Plot type(s): normal plots

Non-overlapping plots:

6642

7000

line upload: no

Online search: no

Total no. of plot observations:

6642

Number of sources (biblioreferences, data collectors):

308

Export format(s): TURBOVEG, MS Access, Excel

Countries (\%): Spain: 71; France: 22; Portugal: 1.9; Andorra: 0.42

Formations: Forest: $100 \%$. Terrestrial: $100 \%$

Guilds: all vascular plants: $100 \%$

Environmental data (\%): altitude: 98; slope aspect: 73; slope inclination: 68

Performance measure(s): cover: $100 \%$

Geographic localisation: GPS coordinates (precision $25 \mathrm{~m}$ or less): $0 \%$; point coordinates less precise than GPS, up to $1 \mathrm{~km}: 42.7 \%$; small grid (not coarser than $10 \mathrm{~km}$ ): $52.3 \%$; political units or only on a coarser scale ( above $10 \mathrm{~km}$ ): $5 \%$

Sampling periods: before 1920: 0\%; 1920-1929: 0\%; 1930-1939: 0.34\%; 1940-1949: 1\%; 1950-1959: 2.5\%; 1960-1969: 6.2\%; 1970-1979: 8.3\%;

1980-1989: 35.2\%; 1990-1999: 29.16\%; 2000-2009: 14\%; 2010-2019: 3.3\%; unknown: 0\%

Information as of 2020-12-07 further details and future updates available from http://www.givd.info/ID/EU-00-023

\section{Acknowledgements}

The development of the Information System of the Iberian and Macaronesian Vegetation (SIVIM) was supported by the Spanish Ministry of Education and Science (Projects CGL2006-13421-C04 and CGL2009-13317-C03). Juan Antonio Campos was supported by the Basque Government (projects IT299-10 and IT936-16).

\section{E-mail and ORCID}

Juan Antonio Campos (Corresponding author, juanan.campos@ehu.eus), ORCID: https://orcid.org/0000-0001-5992-2753

Arnau Mercadé (arnaumerc77@hotmail.com), ORCID: https://orcid.org/0000-0002-1817-1559

Xavier Font (xfont@ub.edu), ORCID: https://orcid.org/0000-0002-7253-8905 